\title{
MINDSET PATTERNS OF NEWCOMERS TO ORGANIC FARMING IN HUNGARY
}

\author{
Enikő Varga ${ }^{1}$, Zoltán Baracskai
}

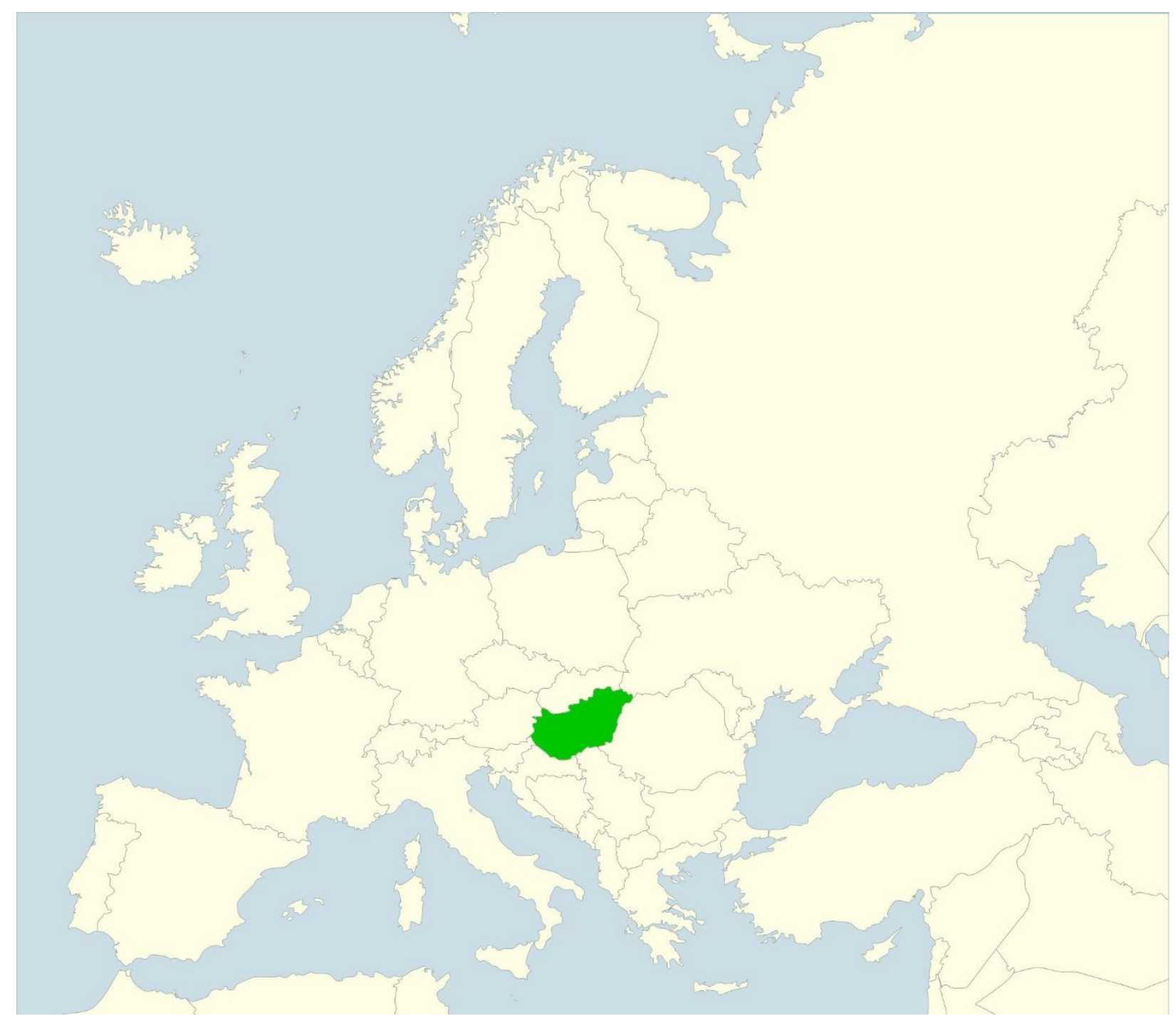

\footnotetext{
1 Enikő Varga, Doctoral School of Regional Sciences and Business Administration, Széchenyi University, Győr, Hungary. ORCID: 0000-0002-5559-872X; e-mail: varga.eniko@sze.hu

2 DSc. Zoltán Baracskai, Széchenyi University, Győr, Hungary; ORCID: 0000-0002-1450-8484; e-mail: baracskai.zoltan@sze.hu
} 
Abstract: Counterurbanization, rural in-migrant trend studies rarely focus on the individual decision-making process. This paper studies the mindset patterns and frames the decision to select organic farming as a next career. We aimed to deepen our understanding of the complex reasoning that motivates newcomers to choose organic farming on a personal level. Based on semi-structured interviews, we developed a questionnaire and collected data from the newcomer to organic farming community in Hungary. The responses were analyzed using: (1) factor analysis to assess the dimensionality of the factors and (2) knowledge-based expert system to identify the logical connections between the aspirations. Our conceptual model was developed based on if-then rules between the identified aspirations, which describe the mindset patterns of newcomers to organic farming.

Keywords: counterurbanization, newcomers to organic farming, mindset patterns

\begin{abstract}
Absztrakt: Nem ismert, hogy az öko-farmokon újrakezdök milyen gondolkodási folyamat nyomán választják a gazdálkodást tanult szakmájuktól távol álló karriernek. Ez a cikk feltárja az öko-farmokon újrakezdök döntései mögött lévő gondolkodást. Célunk az ökofarmokon újrakezdők gondolkodásában használt minták megértése volt. Lazán struktúrált interjúk alapján adatokat gyüjtöttünk a magyarországi öko-farmokon újrakezdőktöl. Az adatokat elöször faktoranalízissel elemeztük, majd egy mesterséges intelligencia alapú szakértői rendszerrel feltártuk a jelenséget kiváltó gondolkodás logikai szabályait. A jelenség megértéséhez a bemutatott fogalmi keret az elvárások közötti ha-akkor szabályokkal írja le az öko-farmokon újrakezdök döntését.
\end{abstract}

Kulcsszavak: menekülés a városból, öko-farmokon újrakezdők, gondolkodási minták

\title{
Highlights
}

- Changing profession, lifestyle to become organic farmer is an emerging phenomenon.

- Modelled the decision maker's aspirations with a Knowledge Base System.

- Described the connections between the newcomers' aspirations with if-then rules.

\section{Introduction}

Handy (2015) uses the metaphor of the sigmoid curve, the S-curve, to represent changes in business, society, career trajectories, or any other progression typified by periods of growth and decline. It also offers strategies to manage those changes over time. Following common business wisdom, the best time to start a new curve is before one reaches the peak of the current curve, when resources and motivation are plentiful enough to progress to new heights. In one's professional and personal life, more than one S-curve can appear, but it is difficult to identify which factors influence the decision to shift from one curve to the next.

Milone \& Ventura (2019) study the new generation farmers in Italy whom they call "new peasants". These farmers are often people with non-agrarian degrees who decide to create land-based rural enterprises. The move to rural is observed widely (Ní Laoire, 2007; Halfacree, 2008; Oliveira \& Penha-Lopes, 2020) although there is no strict record of the individuals who change lifestyle and/or profession to become new peasants or newcomers to farming. Counter-urbanization in Central Eastern Europe, which follows similar trends to its western counterpart (Brown, Kulcsár, Kulcsár, \& Obádovics, 2005; Csurgó, 2013; Šimon, 2014).

It would be superfluous to detail literature on the impact of the digital technology on everyday-life, teaching, learning, business models. However, it is fundamental to consider it in the understanding of the new peasants' environment. These concepts lead us to the definition of Organic Cyber Farmer to describe those who select organic farming as their new S-curve by 
moving to a rural area to start an enterprise, venturing out from their original profession and leveraging the digital age for learning and business opportunities. They leverage the digital era for knowledge increase; search and share practices through the internet. As this paper does not treat the use of information technology, therefore in the current paper we use the concept Newcomer to Organic Farming instead of the aforementioned Organic Cyber Farmer.

Several concepts emerge in the study of selecting organic farming as a new S-curve: new peasants, move from urban to rural (counter-urbanization), narratives, digital era, organic farming, decision making, tentative definition of aspiration levels. Therefore, we bind to those that are strongly connected with our understanding of the phenomena.

This paper is organized as follows: the theoretical background section presents a short overview of counter-urbanization, human decisions for a tentative definition of the aspiration levels. The following section describes the Approach, offers an explanation as why Knowledge Acquisition supported by a Knowledge Based System is an appropriate method of study. Our findings of the analysis are presented in the Mindset patterns to select organic farming as a new S-curve section, followed by the Discussion and Concluding remarks.

\section{Theoretical background}

Mitchell (2004) argues that the concept of counter-urbanization is too broad to cover its depth of meaning. She distinguishes three types of migration: ex-urbanization, displaced- urbanization and anti-urbanization. Ex-urbanization is the movement from the city to rural of those who perceive a limited dream of the countryside. Displaced-urbanization is the move of individuals or families who search for job opportunities in the rural attracted either by land or property prices. Antiurbanization consists of those individuals who reject the urban lifestyle, defined as: (i) back to the land movement, (ii) relocation to enhance quality of life, (iii) retirement migration (Mitchell, 2004; Stockdale \& MacLeod, 2013; Stockdale, 2014). The concept of "rural gentrification" also emerges in several studies on counter-urbanization (Phillips, 2010; Halfacree, 2012). Shucksmith (2018) approaches the phenomena from the "rural idyll" narrative perspective, which sees the rural idyll as "something to which many aspire, perhaps as a vision of a good place to live or as a repository of values" (Shucksmith, 2018: 163). Stockdale (2014) similarly studies the decision-making process to migrate to rural areas in the United Kingdom and argues that the process should not just be understood as an effort to change the quality of life, that is, the rural idyll narrative. He concludes that those who move to rural areas disguise the true nature of the migrant decision-making process; the decision to move to rural may not be a rational, conscious decision. Studies on suburbanization and counter-urbanization in Hungary conclude that migration flows are comprised of both economic and lifestyle motivated migrants (llcsikné Makra, Bajmócy, \& Balogh, 2018; Bajmócy, Hosszú, Dudás, \& Balizs, 2011). Csurgó (2013) identified three types of counter-urbanizers: the rural idyll representation type, the rural family idyll representation type and the rural as garden-city representation type.

Although related, identity and attitudes are different constructs. One's identity defines how one thinks about oneself, how one views the world and one's environment. Identity is affected by society. An attitude is an opinion, belief, or preference. For example, one can view oneself as a farmer (identity) and not favor the use of pesticides (attitude towards farming practices, processes) (Sulemana \& James, 2014). Seabrook \& Higgins (1988) highlight that the image farmers hold about themselves significantly affects their behavior and the decisions they make about the practices and processes used in their farming business. Schöll \& Binder (2010) compared present and future mental models of farmers towards pesticide use and identified three types: deductive effect-focused farmer, deductive cause- focused farmer, imaginative effectfocused farmer. Becker (2006) defines Homo Ecologicus as "characterized by (a) sympathy with and respect for nature, (b) orientation of its own creativity upon the creativity found in nature, and (c) a relationship with nature, which is especially based on personal experience and encounters with it". (Becker, 2006:18) In line with the Homo Ecologicus definition newcomers to organic farming adopt environmentally-friendly farming practices.

Kahneman (2013) describes the thought process using the metaphor of two systems. "System 1" produces fast thinking. It makes quick judgments based on familiar patterns and works 
automatically and effortlessly. "Fast thinking includes both variants of intuitive thought - the expert and the heuristic - as well as the entirely automatic mental activities of perception and memory" (Kahneman, 2013:13). "System 2" produces slow thinking. It requires more intense focus, takes much effort and operates methodically. These two systems interact continually but not always smoothly. To understand the decision-making process when selecting the new S-curve, one has to consider the decision maker's thinking process and aspirations. In accordance with Simon (1977), we understand the process of taking action on a decision as comprised of three principal phases: finding an occasion to make a decision, exploring different courses of action and, finally, choosing from those courses of action.

In the study of the human thought process, the concepts Econs and Humans emerged (Thaler, 2015). Homo Economicus (Econs) is rational and economical models were built based on the assumption that all decisions are inherently rational. From that perspective, there is no differentiation between what we want and choose; choices simply reveal preferences. However, to understand behavior, there is a need to study "Humans" rather than Econs". Due to the heterogeneous characteristics of counterur-banizers, including lack of experience and the variety of aspirations, the Econ-mindset does not give us relevant insights regarding the future of newcomers to organic farming. Therefore, in accordance with Thaler (2015), we reflect on an important concept, self-control, which arises when preferences are inconsistent across time or context. Ariely (2008) suggests that almost everyone has problems with procrastination and selfcontrol, but those who recognize and admit these weaknesses are more successful in overcoming them. Our expectations influence our views of subsequent events. They also shape stereotypes, which are understood as a way of categorizing information. Even when faced with new scenarios, our cognitive processes do not start from scratch. Instead, they build upon previous experiences.

Bruner (1986) argues that we organize our experiences and our memory of events mainly in the form of narratives, stories, and myths. Recently, the situation has reversed. We can almost say that we expect too much from narratives. Therefore, newcomers to organic farming should be aware that even if they don't have narratives about farming, they are exposed to several narratives related to rural lifestyle like healthy living, coevolution with nature, rural idyll and many more. 'We give different 'reality' status to experiences we create from our differently formed encounters with the world. We place a canonical value on certain stances that yield certain forms of knowledge, certain possible worlds." (Bruner, 1986:110)

According to March (1978), decisions are driven by expectations, incentives, and desires. One has to evaluate the possible solutions, the consequences that follow the solutions, and then choose those solutions which promise consequences most congruent with one's desires. In the decision-making process, solutions and expectations are not known but have to be discovered or developed. This introduces uncertainties and errors; decisions are intended to be rational but are bounded by human limitations. Therefore, aspirations and search rules are adjusted over time in response to experience (March, 1991). Previously, researchers resisted studying narratives, although they play an important role in the development of thought processes. They determine the aspirations that contribute to motivating which decisions happen here and now.

We considered the sigmoid curve, S-curve (Handy, 2015) as a starting point of our study. We speculated whether the moves are mostly driven by the "rural-idyll" narrative, the pull of the countryside rather than push factors. The goal of our research was to surface the aspirations, intuitive knowledge (Kahneman, 2013) of decision makers, in order to deepen our understanding of an emerging phenomenon: newcomers to organic farming. Our propositions were as follows: i) people in different stages of the decision process have different mindset patterns ii) understanding of the Newcomers' reasoning is attained through unfolding several mindset patterns for selected aspirations.

\section{Methodology, approach to identify mindset patterns}

Transdisciplinary approach has been considered a way to address complex societal problems, which cross disciplinary boundaries(Costanza, 1991; Horlick-Jones \& Sime, 2004; Max-Neef, 2005; Pohl, 2008; Popa, Guillermin, \& Dedeurwaerdere, 2015; Polk, 2015; del Cerro Santamaría, 2015; Guimarães, Pohl, Bina, \& Varanda, 2019). 
We based our work on Nicolescu's (2014a) conceptualization of transdisciplinarity. To describe the individual disciplines, he used the metaphor of birds in their cages. The bird from its cage observes the reality through the grids of the cage, which represents mono-disciplinary approach. In this scenario, what the bird sees from the cage is partial and subjective, however the bird could think that it observes reality as it is. Multidisciplinary approach could be to have the birds "talk" to each other, which could bring a richer picture of the reality. Along this metaphor, interdisciplinarity would mean bringing the birds over the other's cages, in this way methods, tools, approaches would be shared. Transdiscplinarity, which goes beyond the disciplinary boundaries would mean the opening of the doors of the cages, so the birds could fly freely. Our research problem determined our approach, which similarly to every real problem resist to mono-, multi- or interdisciplinary frameworks. According to Max-Neef (2005) transdisciplinarity is a manner of seeing the world more holistically.

To understand the mindset pattern of a newcomer to organic farming we need to consider concepts like counter-urbanization, human decisions and social narratives. Therefore, we share the view on the notion of transdisciplinary as being considered to go beyond the conceptions of scientific disciplines and to try to integrate and synthesize many different disciplinary perspectives. According to Jahn, Bergmann, \& Keil (2012), the transdisciplinary approach should use simple language shared by disciplines and understandable by society. The capacity to transgress disciplinary or professional boundaries, by common understanding to "think out of the box" is considered as a characteristic of transdisciplinary inquiry (Lawrence, 2015).

In our approach, we chose to adopt Nicolescu's transdisciplinary methodology. "After many years of research, we have arrived at the following three axioms of the methodology of transdisciplinarity: 1. The ontological axiom: There are, in Nature and society and in our knowledge of Nature and society, different levels of Reality of the Object and, correspondingly, different levels of Reality of the Subject. 2. The logical axiom: The passage from one level of Reality to another is ensured by the logic of the included middle. 3. The complexity axiom: The structure of the totality of levels of Reality or perception is a complex structure: every level is what it is because all the levels exist at the same time." (Nicolescu, 2014b, p. 21) Therefore, we distinguished between different levels of reality. Transdisciplinary approach was used as a framework to understand the Newcomers' to Organic Farming reality.

Harmonized with the ontological axiom of Nicolescu $(2010,2014)$ that every newcomer's to organic farming decision is made on a personal level, we observe the mindset patterns on the personal level. In our study, we exclude both the organizational and the social levels.

To understand the mindset patterns, a questionnaire was prepared based on semi-structured interviews (Saunders, Lewis, \& Thornhill, 2007). The order of questions varied depending on the flow of the conversation; additional questions emerged, which helped to develop the questionnaire. Interviewees used words, concepts in a particular way, which gave the opportunity to probe the meanings of them. The survey questions were grouped into five sections: 1.) to segment the population into three groups (already organic farmer, in-process and thinking-about-it); 2.) to understand the initial state (where do you come from?) 3.) to identify the reasons behind becoming organic farmer (push); 4.) to understand the achieved or desired state (where did you go?); 5.) to identify the influencing factors of the change (pull). From the perspective of decision-making, it is important to distinguish the three groups of respondents. Those who are already organic farmers answer the questionnaire after making a decision. For the in-progress group, the decision is made, but not necessarily acted upon, and may or may not be reversible. The thinking-about-it group may still be evaluating potential alternatives. The survey was validated with an eight-member focus group consisting of representatives from the three identified groups. The focus group in this setting was used to pre-test the survey questions (Cyr, 2019)(Morgan, 1997) The objective was to craft, validate context specific questions of the survey. As a result, some of the survey questions and answers were revised, to ensure all dimensions of a particular topic were covered in the survey. Approaching people to share, reveal their own personal life-stories, feelings, thoughts, emotions we had to consider trust and vulnerability. 
Counter-urbanization is conspicuous in Hungary today. Despite this, measuring the exact population, those who selected organic farming as a new S-curve is difficult since records are rarely kept.

We estimated the size of the population that selected organic farming as a new "S-curve" by: (i) Gathering data from the organizers of the "Gyüttment" festival in Hungary. "Gyüttment" festival is an annual knowledge-sharing event for city-to-rural migrants. It focuses on topics ranging from sustainability, permaculture, and social enterprise. In 2018 the festival had approximately 4000 attendees According to the Pareto rule, $20 \%$ of 4000 people would mean an estimate of 800 people who start farming when they move to rural areas. The organizers estimated the population to be around 1500. (ii) Counting the followers of three social media groups: "Gyüttment" (12970 followers on 2019.05.02), "Permakultúra: agrár+" (7989 members on 2019.05.02) and "Ökológiai gazdálkodás - Organic farming" (3908 members on 2019.05.02). (iii) Gathering data from the professional organization, Ökológiai Mezőgazdasági Kutatóintézet (ÖMKi) Közhasznú Nonprofit Kft., a representative of the Hungarian organic agriculture, a partner of two international organizations: FIBL (Forschungsinstitut für Biologischen Landbau) and IFOAM (International Federation of Organic Agriculture Movements). In ÖMKI's on-farm network, there are dozens of organic farmers from non-agrarian professions who choose farming as their next "S-curve". Using these inputs with a conservative approach, we estimated 1000-1500 people who choose organic farming in Hungary as their new "S-curve", over a 5-year period from 20142019.

The data collection was performed by targeted email sent by the Newcomers to Rural festival organizers, followed by sharing the survey on the mentioned social media groups. We received a total of 95 responses as of January 2019. Considering the estimated size of the population and the response rate, the findings from the dataset are not generalizable. However, we considered the dataset as a starting point for an initial attempt to understand the phenomenon, to identify commonalities in the mindsets of those who select or consider to select organic farming as their next S-curve. Therefore, the results of the current study could be considered as the starting point for future enquiries, either for additional data-collection, or alternatively for refinement of the aspects of the decision-making.

In the data analysis, two methods were used: Varimax Factor Analysis to identify the factors which describe the phenomenon and a Knowledge Based System to reveal the logical relationships between the aspirations.

Knowledge Based Systems as a field of Artificial Intelligence have been evolving for decades, with application in several industries, different areas, fields (Wagner, 2017). Knowledge representation techniques also range from rules to cognitive maps, frames (Wagner, 2017; Gavrilova \& Leshcheva, 2015). When working with Knowledge Based System, the knowledge acquisition process starts with the formulation of the aspects of the decision. Aspects of the decision or aspirations, as defined by March (1991), are called attributes in the Knowledge Based System. The attributes and their values are given by the expert, decision maker. In this sense, an attribute is a decision criterion. Once the attributes and their values are defined, the next step is to acquire the cases including the outcome for each of them.

The knowledge acquisition process for the knowledge base in this study consisted of building the survey, validating the survey and the coding of the responses. Through this process, we brought the aspirations and their levels to light. To represent knowledge, the Knowledge Based System uses symbolic logic, in which knowledge is expressed by logical statements, if-then rules between the attributes.

The Knowledge Based System used in our research has Case Based Reasoning functionality. It infers the if-then rules using an entropy-gain method. The attributes are taken one-by-one to form subsets according to their values. Their strength in making an order is measured by an entropygain (informativity) calculating algorithm (ID3) (Quinlan, 1986). The result of the Cased Based Reasoning is the Case-Based Graph or induction tree which describes the rules induced from the identified cases (Velencei, 2017). The most informative attribute is chosen as the root of the induction tree and the first level subsets are formed according to the most informative attribute's values. These subsets are further divided using the same algorithm until all subsets 
are homogenous. When a homogenous subset is formed, it is not divided further; it becomes a leaf of the graph. The benefit of the Case Based Reasoning is that the number of attributes is reduced, and only the most informative attributes remain. In the Case Based Reasoning process several attributes can be considered as benchmark attributes. The benchmark attributes are those which are evaluated based on the rest of the attributes. From the results of Case Based Reasoning, the important aspects of the decision can be determined using reduction by extracting the rules from the induction tree. Reductive Reasoning, which follows Case Based Reasoning, aims to describe the phenomenon at hand with the smallest number of attributes implemented according to the fitness function as defined by Tam \& Cheung (2000).

An overview of our approach to understand the mindset patterns of newcomers to organic farming is presented in the Fig 1.

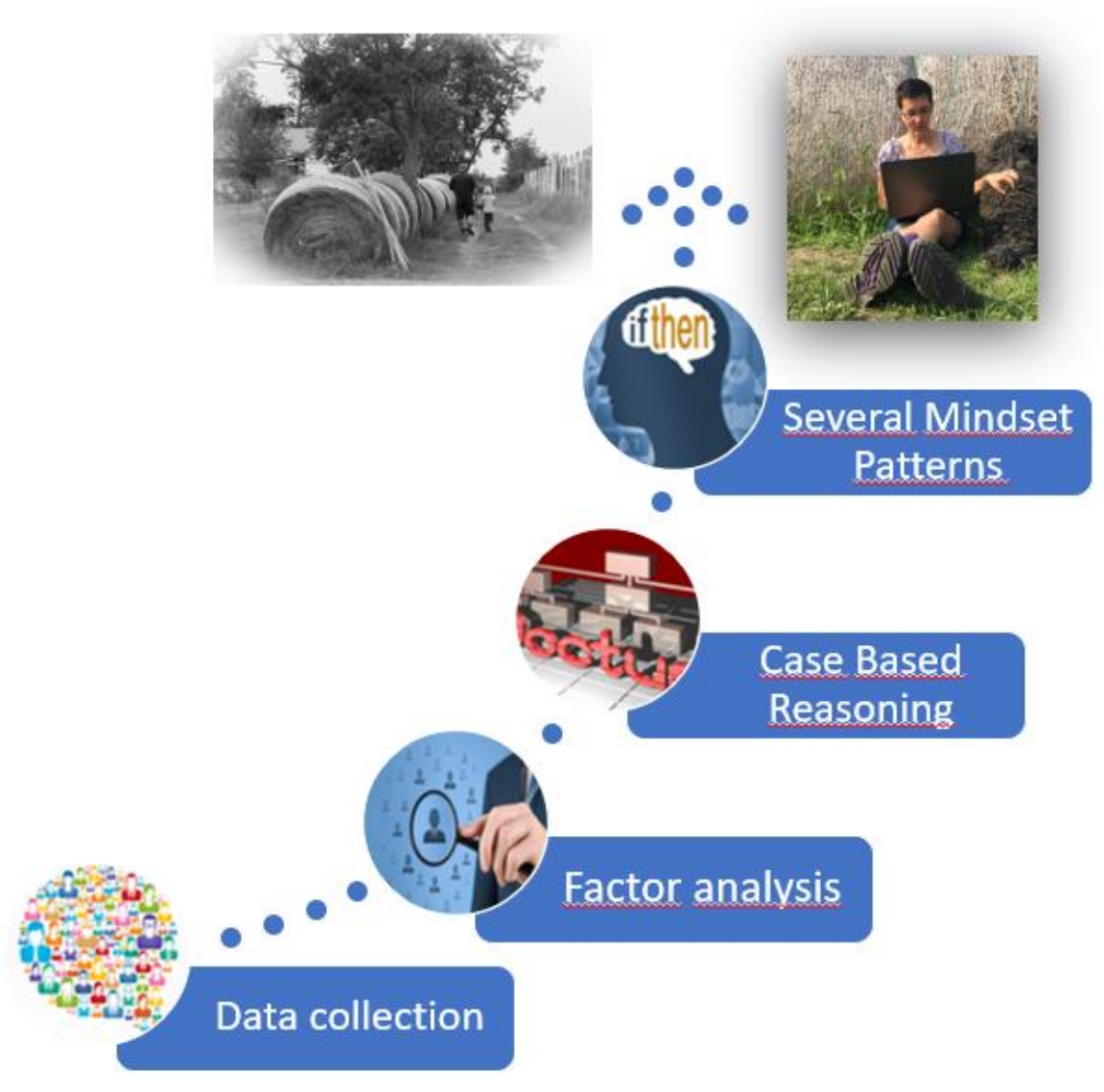

Fig 1. Approach to identify mindset patterns for newcomers to organic farming. Source: own elaboration

The steps of our empirical study were: data collection; attribute and value assignment; data evaluation with factor analysis and Knowledge Based System considering several benchmark attributes. The responses from the survey were coded for factor analysis. Similarly, for the analysis with Knowledge Based System, the responses were translated into succinct attributes and values.

The attributes and their assigned values for the Knowledge Based System:

1. Organic farmer: already organic farmer, in-process, thinking-about-it

2. Number of workplace changes: more than four times, less than four times, none

3. Dominant profession selection: by accident/chance, heard about it, experienced it, I don't change a workplace, I don't have a conception

4. Profession change so far: close-once, close-several times, none, distant-once, distantseveral times 
5. Knowledge acquisition for current profession: autodidact, learning by doing, school system, course, all learning types

6. Reason for change: burnout, family, had enough of the city, company bankruptcy, health

7. Last workplace: challenge: bored for a long time, bored recently, just right, worried

8. Last workplace: personal relationships: opportunist, alright, conflict with the boss

9. Last workplace: compensation: underpaid, limited, proper but unreliable, satisfied

10. Shift: workplace good example, blue ocean, challenge, I don't change a workplace, I don't have a conception

11. Shit: profession: irrelevant but something different, I don't have an idea, I have experience with

12. Shift: living space: self-supplying (passive), homestead, village, edge of the city

13. Influencer: community, friends, family

14. Place popularity: it has fantasia, popular neighborhood, not popular, all the same

15. Risk taking: golden mean, risk taker, risk averse

\section{Results-Mindset patterns to select organic farming as a new S-curve}

\subsection{Results of factor analysis}

Our proposition was that the mindset patterns of those who selected organic farming as a new $S$ - curve can be understood by defining the aspirations and their values. After coding the survey results, we started the assessment with factor analysis performed on the whole dataset. The first results indicated that the phenomenon can be described with fifteen factors, meaning that the model is ill-structured. The second factor analysis was performed on a reduced dataset by excluding the sample of the thinking-about-it category. This reduced dataset was used in a subsequent analysis, thus, the first question to segment the population became extraneous. The factor analysis for the shortlist (the population consisting of already organic farmer and inprocess) with settings (Principal axis/Varimax, 4 factors) could describe $49 \%$ of the phenomenon. Consequently, the following questions were excluded before the next evaluation: dominant profession selection, reason for change, number of workplace changes, last workplace, and personal relationships. The third factor analysis was performed on the reduced dataset and reduced set of questions with the settings (Principal Axis/Varimax, 4 factors), which led to $60 \%$ of the phenomenon being described with four identified factors, presented on Fig. 2.

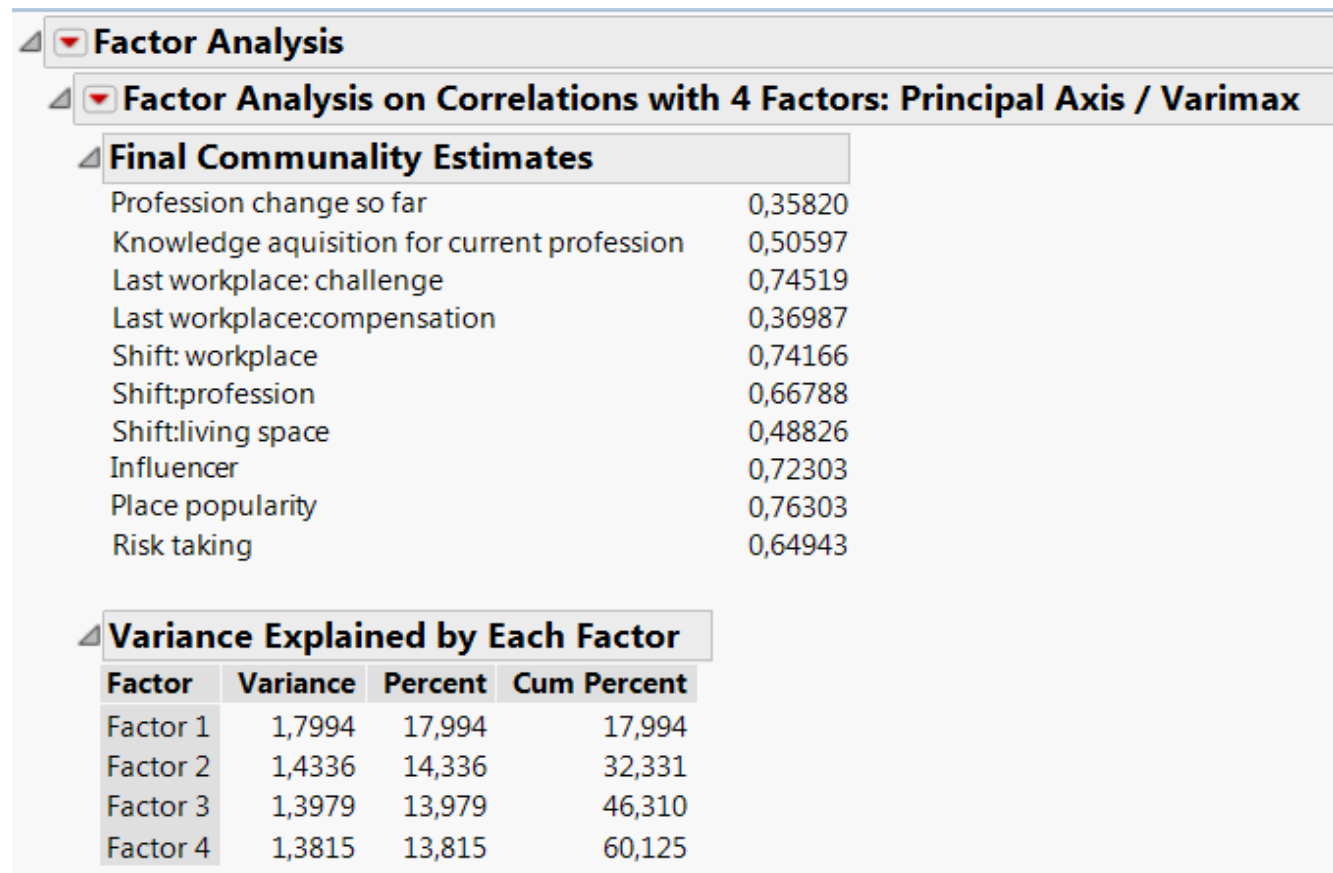

Fig 2. Principal Axis/Varimax/4 factors. Source: own elaboration 
The identified factors were named as follows: Factor 1 - Place definition consisting of two aspirations Shift: living space and Profession change so far; Factor 2 - Influence consisting of two aspirations Place popularity and Influencer; Factor 3 - Change inclination consisting of two aspirations Shift: workplace and Risk taking; Factor4 - Initial state consisting of two aspirations Shift: profession and Last workplace: challenge. Factor analysis showed that in the case of such complex phenomenon, only partial justification (60\%) is possible. An important finding of this analysis, consistent with the literature, is that the decision(s) to change profession and/or lifestyle in the case of the newcomers to organic farming are more complex than the commonly mythologized rural-idyll narrative or change in quality of life (Bijker, Haartsen, \& Strijker, 2012; Stockdale, 2014). As the phenomenon is so new, no strong rule-sets were priorly shaped, and the identified four factors describe it only partially. However, we were not content with this outcome, since it did not lead us any closer to revealing the decision maker's mindset. Central to our thesis was that understanding the newcomer's to organic farming mindset is essential to understanding the phenomenon. Consequently, we searched for a method with which we can refine the previous results. Henceforth, we present the results of the supplemented analysis with Knowledge Based System. With Knowledge Based System, several different acceptable mindset patterns were unfolded by considering different attributes as benchmark attributes for the three groups (1) already organic farmer, (2) in-process, (3) thinking-about-it. It would be superfluous to present all, so we limit the presentation of the models for the newcomers to organic farming mindset patterns to three benchmark attributes: reason for change, shift: living space, knowledge acquisition for current profession.

\subsection{Mindset patterns for Reason for change}

The decision to move from one S-curve to a new one either by changing lifestyle or profession is a decision where previous experiences are rare. In factor analysis the reason for change was excluded. Therefore, in the analysis with Knowledge Based System, we considered it as a benchmark attribute to get an insight in the mindset patterns behind the reasons to become newcomer to organic farming.

Firstly, we considered the group: already organic farmer. Fig 3 is a representation of the rules in a form of an induction tree. The "if- then" rules are read from the root of the graph towards each leaf. One representation of the mindset patterns for the already organic farmer group can be done with five attributes: Last workplace: compensation, Shift: workplace, Place popularity, Last workplace: challenge, Knowledge acquisition for current profession.

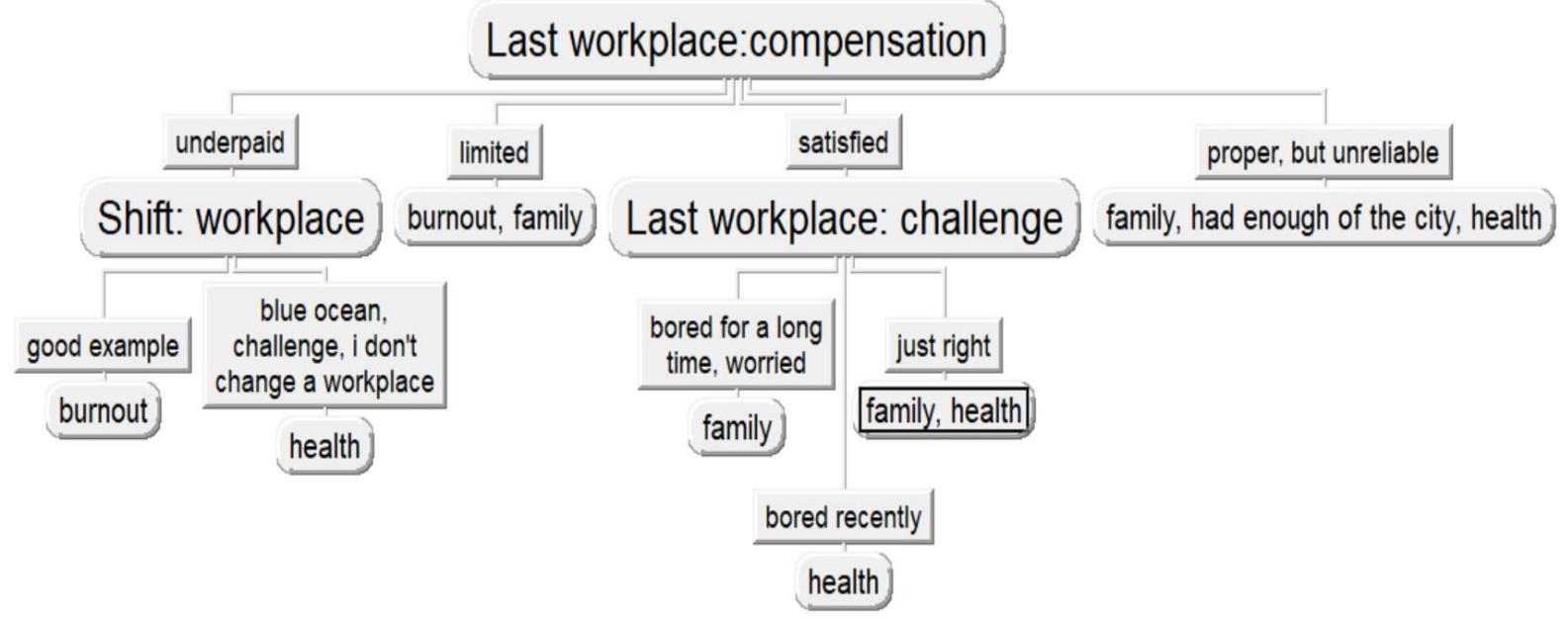

Fig 3. Induction tree for Reason for change as benchmark attribute, group: already organic farmer. Source: own elaboration 
Two examples of if-then rules from the induction, representing the mindset patterns for the newcomers to organic farming can be read as follows:

If Last workplace: compensation is "underpaid" and

Shift: workplace is "good example"

Then Reason for change is "burnout".

If Last workplace: compensation is "satisfied" and

Last workplace: challenge is "bored recently"

Then Reason for change is "health".

Secondly, in the analysis of the attribute Reason for change for the group in-process, the following attributes were identified in one representation of the mindset patterns: Shift: living space, Profession change so far, Last workplace: challenge, Dominant profession selection, Knowledge acquisition for current profession. Fig 4. represents the in-then rules in a tabular form. The values of the attributes are read from left to right. Asterisk $\left(^{*}\right)$ means that the attribute does influence the rule.

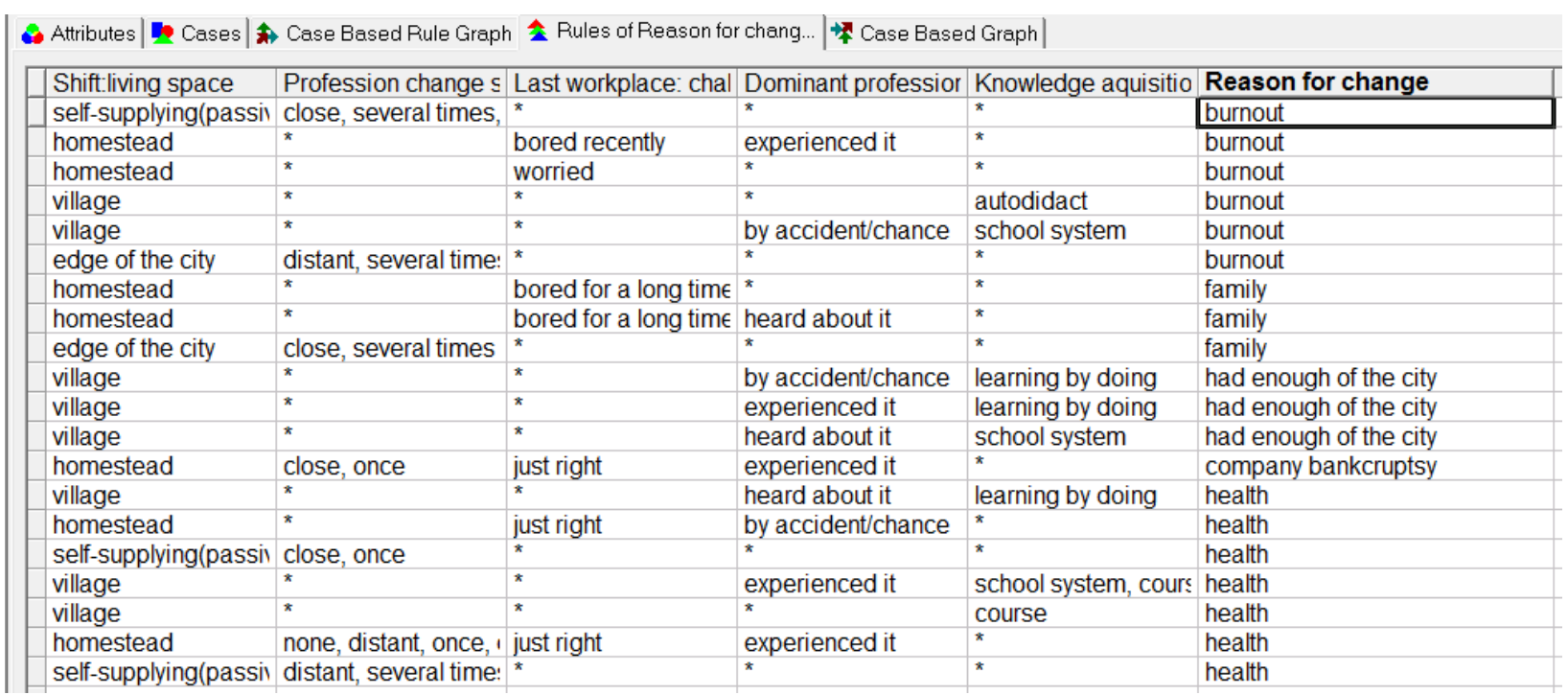

Fig 4. Rules for Reason for change, group: in-process. Source: own elaboration

Examples of if-then rules for the group in-process for Reason for change $2^{\text {nd }}$ from the top and $3^{\text {rd }}$ from the bottom:

If Shift: Living space is "homestead" and

Last workplace: challenge is "bored recently" and

Dominant profession selection is "experienced it"

Then Reason for change is "burnout".

If Shift: Living space is "village" and

Knowledge acquisition for current profession is "course"

Then Reason for change is "health".

Thirdly, the analysis of the attribute Reason for change as a benchmark for the group thinkingabout-it demonstrated that no recognizable pattern could be identified. The models from the Knowledge Based System showed that for this group, there is an evolving mindset pattern that is scattered and disorganized. One model consisted of the following six attributes: Number of workplace changes, Knowledge acquisition for the current profession, Shift: workplace, Shift: 
living space, Place popularity, Influencer. Analysis of the Reason for change attribute for the three groups demonstrated different patterns. For those who are already organic farmers, the most common reasons identified were family and health. For the individuals in the groups in-process and thinking-about-it, the main reasons for the change were health or burnout. Those who are inprocess have very vivid memories of burnout. The same applies to the thinking-about-it group. There can be different explanations for these results. One can be that, for the population already organic farmer, the results reflect the true reasons for the change. On the other hand, one can argue that since the responses consider memories from the past, they might have forgotten burnout as their "true" reason for the change. From this, results that the responses in the survey are loosely connected to the event. Rather, they reveal memories, which are inherently flawed. One impediment we observed was that push factors (reasons for leaving) were more prevalent than pull factors for those who have recently made the change. One can argue that the reason behind this is that they have not yet experienced the positive impacts of the change.

\subsection{Mindset patterns for Shift: living place}

To get an insight in the living place selection, we considered the Shift: living space as a benchmark attribute for the three identified groups. The Shift: living space attribute reflects the aspiration of the physical living space. The induction tree displayed on Fig 5 is one representation of the mindset patterns for those who are already organic farmers. The if-then rules were derived from the following attributes: Profession change so far, Reason for change, Shift: workplace, Last workplace: challenge, Knowledge acquisition for current profession.

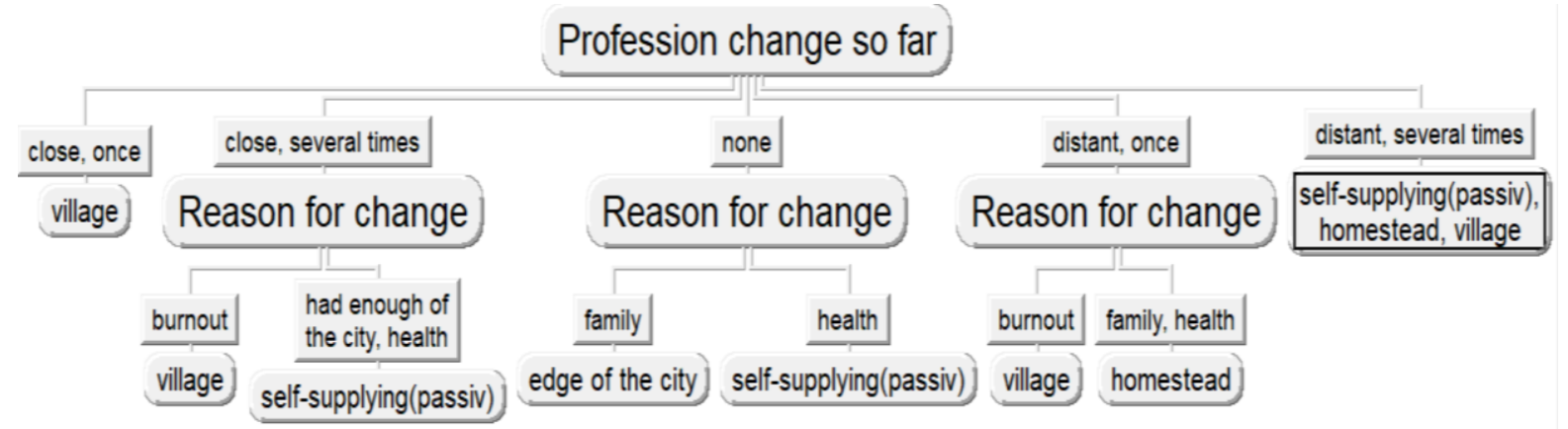

Fig 5. Induction tree for Shift: living space as benchmark attribute, group: already organic farmer. Source: own elaboration

Example of mindset patterns for the Shift: living space for the group already organic farmer from the induction tree can be read as follows:

If Profession change so far is "none" and

Reason for change is "family"

Then Shift: living space is "edge of the city".

If Profession change so far is "none" and

Reason for change is "health"

Then Shift: living space is "self-supplying(passive)".

If Profession change so far is "distant, once" and

Reason for change is either ("family", "health")

Then Shift: living space is "homestead".

Mindset patterns in the induction tree for the group in-process for Shift: living space attribute are visible on Fig 6. The following five attributes were selected to describe the if-then rules: Reason 
for change, Profession change so far, Shift: profession, Last workplace: challenge, Knowledge acquisition for current profession.

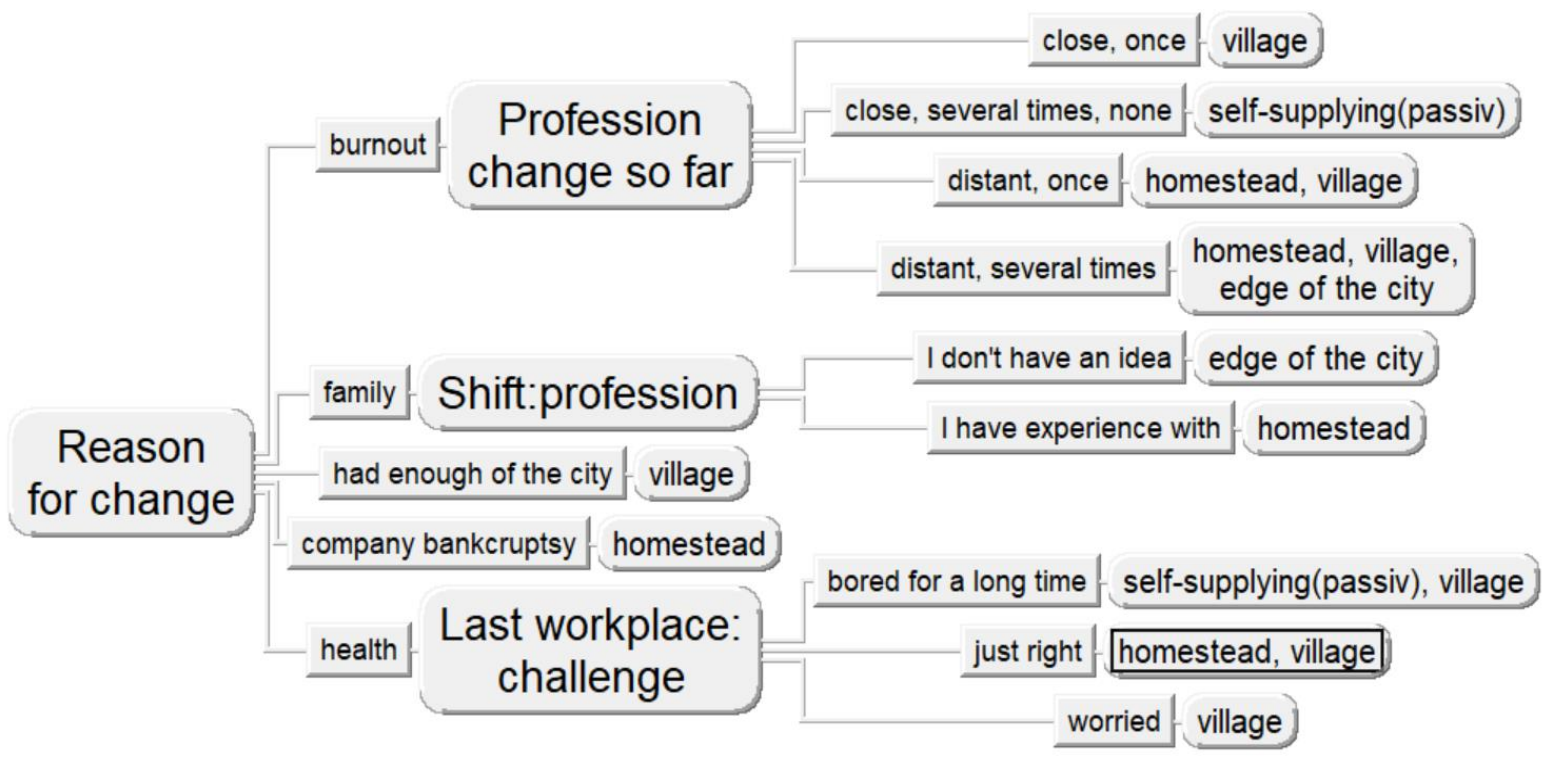

Fig 6. Induction tree for Shift: living space as benchmark attribute, group: in-process. Source: own elaboration

Examples of mindset patterns with if-then rules for the Shift: living space considered as benchmark attribute for the in-process population are as follows:

If Reason of change is "burnout" and

Profession change so far is either ("close, several times", "none")

Then Shift: living space is "self-supplying(passive)".

If Reason for change is "family" and

Shift profession is “I don't have an idea”

Then Shift: living space is "edge of the city".

If Reason for change is "had enough of the city"

Then Shift: living space is "village".

If Reason for change is "health" and

Last workplace: challenge is "worried"

Then Shift: living space is "village".

Compared to the previous group, those who are in-process to become newcomers to organic farming the mindset patterns were described by ambiguous rules. One argument could be that those who are in-process did not fully experience the change yet, which makes it harder to reveal the aspects of their decision.

Shift: living space as benchmark attribute for the group thinking-about-it was defined by the following five attributes: Profession change so far, Shift: workplace, Reason for change, Influencer, Knowledge acquisition for current profession. Examples of mindset patterns for selecting self-supplying (passive) living space for the group thinking-about-it from the induction tree were defined as follows:

If Profession change so far is "none" and

Shift: workplace is "good example" and

Knowledge acquisition for current profession is "learning by doing" 
Then Shift: living space is "self-supplying(passive)".

If Profession change so far is "distant, once" and

Reason for change is "health" and

Knowledge acquisition for current profession is "learning by doing"

Then Shift: living space is "self-supplying (passive)".

If Profession change so far is "distant, once" and

Reason for change is "health" and

Knowledge acquisition for current profession is "learning by doing"

Then Shift: living space" is "self-supplying(passive)".

From the induction tree, it was revealed that the attribute Influencer in this representation does not have an impact to select the living space as self-supplying(passive). Two additional examples of if-then rules considering the Influencer attribute were identified as follows:

If Profession change so far is either ("none", "distant, once") and

Shift: workplace is "I don't change a workplace" and

Influencer is "community"

Then Shift: living space is "homestead".

If Profession change so far is either ("none", "distant, once") and

Shift: workplace is "I don't change a workplace" and

Reason for change is "family" and

Influencer is "friends"

Then Shift: living space is "edge of the city".

From these patterns results, that those who are in the thinking-about-it stage have disordered reasoning as they do not have experience yet. Using the Knowledge Based System, we concluded that the reasoning of this group is complex. This can be considered an important result since it highlights whose mindset patterns are worthwhile for study. The attribute Influencer is not the most informative attribute but still decisive. From the current dataset, those who were only thinking about the change were influenced by the narratives, and this could influence their decisions more than anything else.

\subsection{Mindset patterns for Knowledge acquisition for current profession}

For the analysis of the Knowledge acquisition for current profession attribute as a benchmark, we considered the three different populations in separate knowledge bases. Knowledge acquisition for current profession has a different meaning for each of the three groups. For those who are already organic farmers means knowledge increase in farming. For those who are in-process or only thinking-about-it, this attribute reflects a different meaning: the knowledge increase in their current profession. Although this topic is highly interesting, the knowledge acquisition process in the presented research was studied with limitations.

Using Case Based Reasoning for Knowledge acquisition for current profession as the benchmark for the already organic farmer group, the if-then rules could be described with the following three attributes: Influencer, Reason for change, Risk taking. It is surprising that the mindset pattern for knowledge acquisition was described by Influencer in the case of those who are already organic farmers. There were several mindset patterns which meant that there was no "single truth" or single way that newcomers to organic farming increase their knowledge. Fig 7 is one representation of the mindset patterns in the form of an induction tree for the Knowledge acquisition for current profession attribute. 


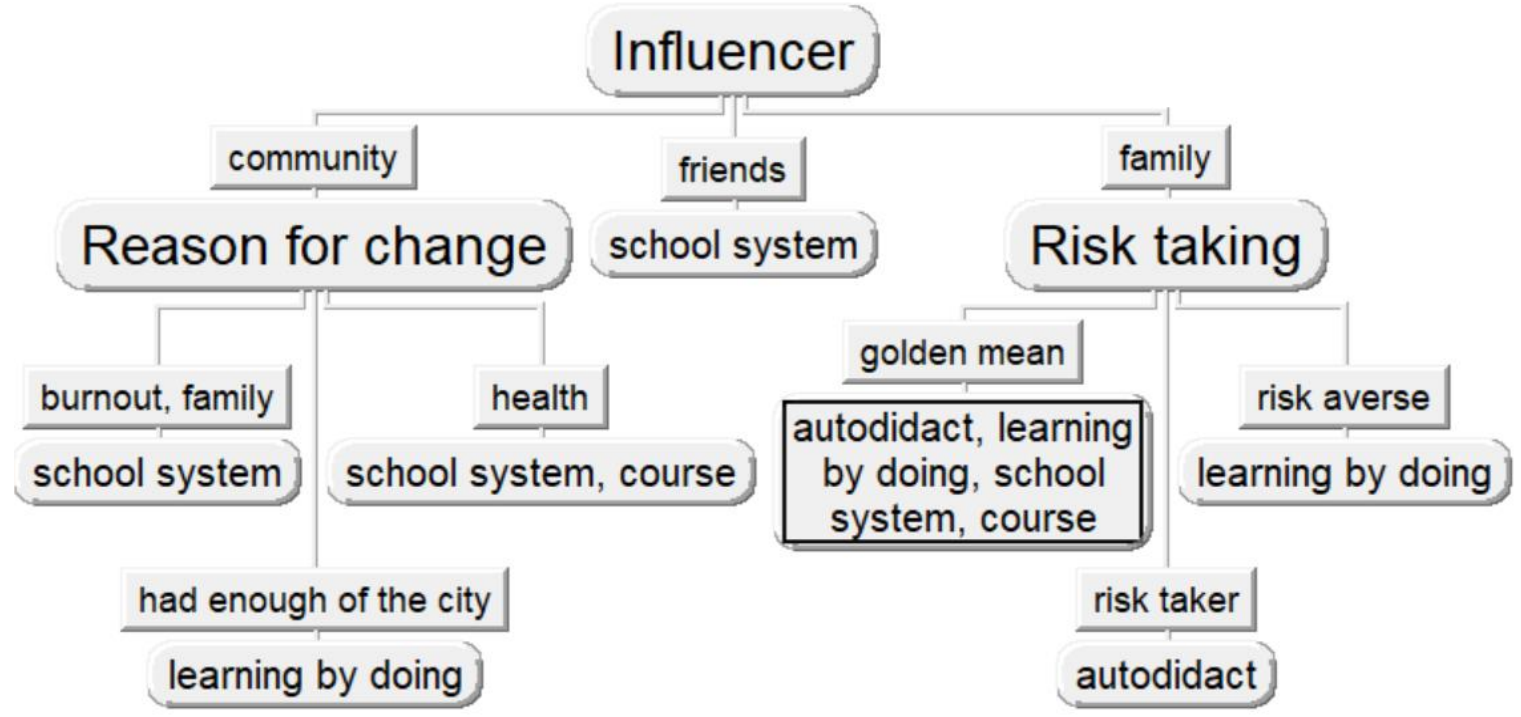

Fig 7. Induction tree for Knowledge acquisition as benchmark attribute, group: already organic farmer. Source: own elaboration

If then rules for the knowledge acquisition for current profession attribute can be read as follows:

If Influencer is "community" and

Reason for change is "had enough of the city"

Then Knowledge acquisition for current profession is "learning by doing".

If Influencer is "friends"

Then Knowledge acquisition for current profession is "school system".

If Influencer is "family" and

Risk taking is "risk taker"

Then Knowledge acquisition for current profession is "autodidact".

In this study, the risk attitude was selected as an attribute with three values (risk-taker, golden mean, risk-averse) without detailing the different contexts of risk-taking, therefore, addressing one's own perception on general risk-taking behavior. Tversky \& Kahneman (1981) describe situations when choices involving gains are risk-averse and choices involving losses are risktaking, noting that the relative attractiveness of the options varies when the decision problem is framed in different ways. If one does not have the experience, or cannot use another's experiences - since others don't have the same experience or get the same results - then prior success or failure cannot influence aspirations. As soon as these experiences happen, aspirations can be adapted into the decision-making process for future newcomers to organic farming. Nevertheless, the risk is unknown, and the aspiration levels of the risk averse newcomer to organic farming develop in a different way than for those who are willing to take risks, and for those who are ready to explore the unknown. In this scenario, risk-taking is an important factor, but we cannot use induction in the inference of the risk levels of a decision alternative. However, we can say that the risk-averse newcomer to organic farming fears the unknown compared with the risk-taker or those who prefer the golden mean. In our analysis of risk-taking as a benchmark attribute, we found that for all three groups, the results of the Case Based Reasoning were illstructured rule-sets. We argue that this is due to self-control reasons. Case Based Reasoning considering knowledge acquisition for current profession as benchmark attribute for the remaining two datasets: in-process and thinking-about-it produced complicated induction trees. Only a few common mindset patterns were revealed, therefore we can conclude that these groups are still looking for the knowledge increase in many ways. Mindset patterns for newcomers to organic farming highlight that autodidact learning is a way considered for knowledge increase. Therefore, we argue that transdisciplinary co-production of knowledge in organic farming (Vandermeulen \& Van Huylenbroeck, 2008; Aeberhard \& Rist, 2009) in today's networked, digital age is an area to be explored in future research. 


\section{Discussion and concluding remarks}

Traditionally, research into counter-urbanization and rural in-migrant trends focuses on the reason to migrate; to focus on the individual process of decision making itself is rare. In doing so, understanding that newcomers to organic farming are part of several complex systems like Mother Nature, World Wide Web, social networks, economy - to name a few - is paramount to understanding the inherent complexity and interconnectivity of the environment in which they make their decisions. Kahneman (2013) provided several evidences that one cannot estimate the size of the population, consequently a number estimated intuitively cannot be validated by rational thinking process, reasoning. According to their studies, these apparently analytical estimates are always biased, as stated by them, we think metaphorically, on the other hand statistics requires us to think about many things at the same time, which is not the way System 1 works. Our overconfidence is the bottleneck to acknowledge our ignorance and the uncertainty of the world we live in. Therefore, in this study and everywhere else, the results from surveys have to be handled with care and responsibility. The results of this study add to the literature by understanding that the three stages of decision-making as described by Simon (1977) are relevant and have to be considered in the study of mindset patterns as people in different stages have different expectations, aspirations, and are influenced by different narratives. Therefore, splitting the responses according to the three groups: (i) already organic farmer, (ii) in-process, (iii) thinking-about-it was essential to understand the factors and reveal the mindset patterns with the Knowledge Based System. Those who are already organic farmers have left their previous profession and/or lifestyle, they are already on the new S-curve. Those who are in-process, they are just starting on the new S-curve, the decision has been made, which may or may not be reversible. For those who are only thinking-about-it, the mindset patterns are scattered, aspirations are only forming, and they can be almost classified as dreamers. From the received responses, it became apparent that the respondents that had concerns with the questions from the survey were those who did not take the time to think through the available options. The mindset patterns presented here help us to understand the reason for the change, living space selection, and the paths to knowledge increase for the newcomers to organic farming. They model the change from one S-curve to another, namely to become newcomer to organic farming in Hungary. The if-then rules are not generalizable across all cases; they are only valid for the examined cases. Our results should be validated inside these boundaries. Adding new cases to the existing dataset through future research, could reveal new rules. It is important to highlight that the reasoning in several of the mindset patterns was reduced to 2-5 attributes, which indicates that in these cases, rules were formed and set. Our aim was to search for the understanding of an emerging phenomenon: the appearance of the newcomer to organic farming, where, based on the survey, we attempted to order their intuitive knowledge and aspirations. For those interested in the phenomenon, future research is suggested in several areas, like into mindset pattern changes on a personal level through longitudinal studies or, alternatively, into the phenomenon on social and/or organizational level.

From the received responses, we encountered the concept of solastalgia. Solastalgia is a neologism created to describe the discomfort, worry and existential distress caused by environmental changes. This area could be a research topic for future elaboration as a possible motive in the move to rural. Another area for further exploration could be the role of the "influencer". We propose to consider narratives (J. S. Bruner, 2004) and thought styles (Fleck, 1979 ) in the exploration of the influencer's role. Furthermore, knowledge acquisition for the newcomers to farming addressed in our paper with limitations is another area of research to be considered.

We do not generalize, but search for an explanation of a phenomenon which triggers thinking and/or action.

\section{Acknowledgement}

This research did not receive any specific grant from funding agencies in the public, commercial, or not-for-profit sectors. 
[1] Aeberhard, A. \& Rist, S. (2009). Transdisciplinary co-production of knowledge in the development of organic agriculture in Switzerland. Ecological Economics, 68(4), 11711181. DOI: 10.1016/j.ecolecon.2008.08.008.

[2] Ariely, D. (2008). Predictably Irrational. The hidden forces that shape our decisions. New York: Harper Collins Publishers.

[3] Bajmócy, P., Hosszú, S., Dudás, R. \& Balizs, D. (2011). New migration trends and their motivation in Hungary. Geographica Timisiensis, 20(2), 29-40.

[4] Becker, C. (2006). The human actor in ecological economics: Philosophical approach and research perspectives. Ecological Economics, 60(1), 17-23. DOI: 10.1016/j.ecolecon.2005.12.016.

[5] Bijker, R. A., Haartsen, T. \& Strijker, D. (2012). Migration to less-popular rural areas in the Netherlands: Exploring the motivations. Journal of Rural Studies, 28(4), 490-498. DOI: 10.1016/j.jrurstud.2012.07.003.

[6] Brown, D. L., Kulcsár, L. J., Kulcsár, L. \& Obádovics, C. (2005). Post-socialist restructuring and population redistribution in Hungary. Rural Sociology, 70(3), 336-359. DOI: 10.1526/0036011054831170.

[7] Bruner, J. (1986). Actual minds, possible worlds. Cambridge, MA: Harvard University Press.

[8] Bruner, J. S. (2004). Life as Narrative. Social Research 71(3), 691-710. DOI: 10.1007/s10780-008-9039-2.

[9] Costanza, R. (1991). Ecological Economics: the Science and Management of Sustainability. New York: Columbia University Press.

[10] Csurgó, B. (2013). Vidéken lakni és vidéken élni. Budapest: Argumentum.

[11] Cyr, J. (2019). Focus Groups for the Social Science Researcher. Cambridge University Press. DOI: $10.1017 / 9781316987124$.

[12] del Cerro Santamaría, G. (2015). Transdisciplinary technological futures: An ethnographic research dialogue between social scientists and engineers. Technology in Society, 40, 5363. DOI: 10.1016/j.techsoc.2014.10.005.

[13] Fleck, L. (1979). Genesis and Development of a Scientific Fact. Chicago: The University of Chicago Press.

[14] Gavrilova, T. A. \& Leshcheva, I. A. (2015). Ontology design and individual cognitive peculiarities: A pilot study. Expert Systems with Applications, 42(8), 3883-3892. DOI: 10.1016/j.eswa.2015.01.008.

[15] Guimarães, M. H., Pohl, C., Bina, O. \& Varanda, M. (2019). Who is doing inter- and transdisciplinary research, and why? An empirical study of motivations, attitudes, skills, and behaviours. Futures, 112, Art. 102441. DOI: 10.1016/j.futures.2019.102441.

[16] Halfacree, K. (2008). To revitalise counterurbanisation research? Recognising an international and fuller picture. Population, Space and Place, 14(6), 479-495. DOI: $10.1002 / p s p .501$.

[17] Halfacree, K. (2012). Heterolocal Identities? Counter-Urbanisation, Second Homes, and Rural Consumption in the Era of Mobilities. Population, Space and Place, 18(2), 209-224. DOI: $10.1002 / p s p .665$.

[18] Handy, C. (2015). The Second Curve: Thoughts on Reinventing Society. New York: Random House.

[19] Horlick-Jones, T. \& Sime, J. (2004). Living on the border: Knowledge, risk and transdisciplinarity. Futures, 36(4), 441-456. DOI: 10.1016/j.futures.2003.10.006. 
[20] Ilcsikné Makra, Z., Bajmócy, P. \& Balogh, A. (2018). Villages on the edge of extinction The Hungarian situation. Journal of Settlements and Spatial Planning, 9(1), 35-45. DOI: 10.24193/JSSP.2018.1.04.

[21] Jahn, T., Bergmann, M. \& Keil, F. (2012). Transdisciplinarity: Between mainstreaming and marginalization. Ecological Economics, 79, 1-10. DOI: 10.1016/j.ecolecon.2012.04.017.

[22] Kahneman, D. (2013). Thinking fast and slow. New York: Farrar, Straus and Giroux.

[23] Lawrence, R. J. (2015). Advances in transdisciplinarity: Epistemologies, methodologies and processes. Futures, 65, 1-9. DOI: 10.1016/j.futures.2014.11.007.

[24] March, J. G. (1978). Bounded Rationality, Ambiguity, and the Engineering of Choice. The Bell Journal of Economics, 9(2), 587-608. DOI: 10.2307/3003600.

[25] March, J. G. (1991). How Decisions Happen in Organizations. Human-Computer Interaction, 6(2), 95-117. DOI: 10.1207/s15327051hci0602_1.

[26] Max-Neef, M. A. (2005). Foundations of transdisciplinarity. Ecological Economics, 53(1), 516. DOI: 10.1016/j.ecolecon.2005.01.014.

[27] Milone, P. \& Ventura, F. (2019). New generation farmers: Rediscovering the peasantry. Journal of Rural Studies, 65, 43-52. DOI: 10.1016/j.jrurstud.2018.12.009.

[28] Mitchell, C. J. A. (2004). Making sense of counterurbanization. Journal of Rural Studies, 20(1), 15-34. DOI: 10.1016/S0743-0167(03)00031-7.

[29] Morgan, D. (1997). Focus Groups as Qualitative Research (2 ${ }^{\text {nd }}$ Ed.). Thousand Oaks: Sage. DOI: $10.4135 / 9781412984287$.

[30] Ní Laoire, C. (2007). The "green green grass of home"? Return migration to rural Ireland. Journal of Rural Studies, 23(3), 332-344. DOI: 10.1016/j.jrurstud.2007.01.005.

[31] Nicolescu, B. (2010). Methodology of Transdisciplinarity - Levels of Reality , Logic of the Included Middle and Complexity. Transdisciplinary Journal of Engineering and Science 70(3-4), 186-199. DOI: 10.1080/02604027.2014.934631.

[32] Nicolescu, B. (2014a). From Modernity to Cosmodernity: Science, Culture, and Spirituality. Albany, NY: State University of New York Press.

[33] Nicolescu, B. (2014b). Multidisciplinarity, Interdisciplinarity, Indisciplinarity, and Transdisciplinarity: Similarities and Differences. RCC Perspectives, 2, 19-26.

[34] Oliveira, H. \& Penha-Lopes, G. (2020). Permaculture in Portugal: Social-ecological inventory of a re-ruralizing grassroots movement. European Countryside, 12(1), 30-52. DOI: 10.2478/euco-2020-0002.

[35] Phillips, M. (2010). Counterurbanisation and rural gentrification: An exploration of the terms. Population, Space and Place, 16(6), 539-558. DOI: 10.1002/psp.570.

[36] Pohl, C. (2008). From science to policy through transdisciplinary research. Environmental Science and Policy, 11(1), 46-53. DOI: 10.1016/j.envsci.2007.06.001.

[37] Polk, M. (2015). Transdisciplinary co-production: Designing and testing a transdisciplinary research framework for societal problem solving. Futures 65, 110-122. DOI: 10.1016/j.futures.2014.11.001.

[38] Popa, F., Guillermin, M. \& Dedeurwaerdere, T. (2015). A pragmatist approach to transdisciplinarity in sustainability research: From complex systems theory to reflexive science. Futures, 65, 45-56. DOI: 10.1016/j.futures.2014.02.002.

[39] Quinlan, J. R. (1986). Induction of Decision Trees. Machine Learning, 1(1), 81-106. DOI: 10.1023/A:1022643204877.

[40] Saunders, M., Lewis, P. \& Thornhill, A. (2007). Research Methods for Business Students $\left(4^{\text {th }}\right.$ Ed.). Harlow: Pearson Education Limited. 
[41] Schöll, R. \& Binder, C. R. (2010). Comparison of farmers' mental models of the present and the future: A case study of pesticide use. Futures, 42(6), 593-603. DOI: 10.1016/j.futures.2010.04.030.

[42] Seabrook, M. F. \& Higgins, C. B. R. (1988). The role of the farmer's Self-Concept in determining farmer behaviour. Agricultural Administration and Extension, 30(2), 99-108. DOI: 10.1016/0269-7475(88)90119-5.

[43] Shucksmith, M. (2018). Re-imagining the rural: From rural idyll to Good Countryside. Journal of Rural Studies, 59, 163-172. DOI: 10.1016/j.jrurstud.2016.07.019.

[44] Simon, H. A. (1977). The New Science of Management Decision. Upper Saddle River, NJ.: Prentice Hall.

[45] Šimon, M. (2014). Exploring counterurbanisation in a post-socialist context: Case of the Czech Republic. Sociologia Ruralis, 54(2), 117-142. DOI: 10.1111/j.14679523.2012.00576.x.

[46] Stockdale, A. (2014). Unravelling the migration decision-making process: English early retirees moving to rural mid-Wales. Journal of Rural Studies, 34, 161-171. DOI: 10.1016/j.jrurstud.2014.01.010.

[47] Stockdale, A. \& MacLeod, M. (2013). Pre-retirement age migration to remote rural areas. Journal of Rural Studies, 32, 80-92. DOI: 10.1016/j.jrurstud.2013.04.009.

[48] Sulemana, I. \& James, H. S. (2014). Farmer identity, ethical attitudes and environmental practices. Ecological Economics, 98, 49-61. DOI: 10.1016/j.ecolecon.2013.12.011.

[49] Tam, S. M. \& Cheung, K. C. (2000). Genetic algorithm based defect identification system. Expert Systems with Applications, 18(1), 17-25. DOI: 10.1016/S0957-4174(99)00046-9.

[50] Thaler, R. H. (2015). Misbehaving- The making of behavioral economics. New York: W.W. Norton and Company.

[51] Tversky, A. \& Kahneman, D. (1981). The Framing of Decisions and the Psychology of Choice. Science, 211(4481), 453-458. DOI: 10.1126/science.7455683.

[52] Vandermeulen, V. \& van Huylenbroeck, G. (2008). Designing trans-disciplinary research to support policy formulation for sustainable agricultural development. Ecological Economics, 67(3), 352-361. DOI: 10.1016/j.ecolecon.2008.05.016.

[53] Velencei, J. (2017). Modeling the Reality of Decision Making with the Doctus Knowledgebased System. In 20th Annual International Conference on Enterprise and Competitive Environment Brno [pp. 865-871].

[54] Wagner, W. P. (2017). Trends in expert Publisher is missingsystem development: A longitudinal content analysis of over thirty years of expert system case studies. Expert Systems with Applications, 76, 85-96. DOI: 10.1016/j.eswa.2017.01.028. 